The Egyptian Journal of Hospital Medicine (Jan. 2012) Vol., 46: 26 - 42

\title{
Effect of Zingiber officinale on fatty liver induced by oxytetracycline in albino rats.
}

\author{
Eman G.E. Helal* , Samia M. Abd El-Wahab ${ }^{*}$, Atef M. Moussa Sharaf** \\ and Ghada A. Zedan ${ }^{*}$ \\ *Zoology Department, Faculty of Science, Al-Azhar University, For Girls. \\ ${ }^{* *}$ Department of Physiology, Faculty of Medicine, Al-Azhar University
}

\begin{abstract}
Background: Fatty liver causes were markedly increased in Egyptian people throughout last years. People prefer to use the medicinal plants instead of using chemical compounds because they are cheap and have few side effects compared to chemical compounds. Ginger is a natural dietary rhizome with antioxidative, anti-inflammatory, and anti-carcinogenic activities. The aim of this study was to evaluate the possible potential therapeutic and protective effects of Zingiber officinale (ginger) against oxytetracyclininduced fatty liver in an attempt to understand its mechanism of action, which may pave the way for possible therapeutic applications.

Material and Methods: Albino rats were divided into two major groups, 15 rats for each. The first group was divided into three sub-groups: a) control, b) fatty liver group; that was injected intraperitonealy with oxytetracycline $(120 \mathrm{mg} / \mathrm{kg})$ for three consecutive days and c) ginger treated group; which was treated with ginger water extract $(125 \mathrm{mg} / \mathrm{kg}$ ) for 30 days after fatty liver induction . All animals were scarified after 33 days of the beginning of the experiment. The second group was divided into three subgroups: a) control, b) fatty liver group; that was injected intraperitonealy with oxytetracycline $(120 \mathrm{mg} / \mathrm{kg})$ for three consecutive days and c) ginger protective group; which received ginger for 15 days before induction of fatty liver, then sacrificed after induction of fatty liver (3 days). Blood samples were collected for biochemical analysis. Liver specimens were obtained and fixed in $10 \%$ formalin for histological study.

Results: Fatty liver groups showed high significant increase in serum glucose, cholesterol, triglycerides, LDL cholesterol, ALAT, ASAT, GGT, LDH, urea, creatinine and A/G ratio while total protein, albumin, globulin and HDL cholesterol were significantly decreased compared to control group. These biochemical changes were accompanied with histopathological alterations in fatty liver tissue. The treatment with ginger ameliorated most of the evaluated biochemical parameters and improved the induced degenerative histopathological changes. The pre-treatment with ginger before the induction of fatty liver gave some protection against factors that experimentally induced fatty liver.
\end{abstract}

Conclusion: Ginger as diet additive is recommend for fatty liver patients or those people who have hyperlipidemic family history.

Keywords: Fatty liver, Ginger, Lipid profile, Rats, Physiological parameters, Histopathology.

\section{Introduction}

Fatty liver, or hepatosteatosis, is characterized histologically by triglyceride accumulation within the cytoplasm of hepatocytes (Ratziu et al., 2010) and refers to fat accumulation in the liver exceeding $5 \%-10 \%$ by weight (Szczepaniak et al., 2005). When hepatosteatosis is present in the absence of excessive alcohol consumption, it is termed non-alcoholic fatty liver disease, or NAFLD (Ratziu et al., 2010, Marchesini et al., 2001), which is considered to be the hepatic manifestation of the metabolic syndrome (Shulman and Mangelsdorf, 2005). NAFLD 
comprises a wide spectrum of hepatic damage, from simple steatosis alone, to inflammatory changes found in nonalcoholic steatohepatitis (NASH) and advanced fibrosis and cirrhosis of the liver. The prevalence of NAFLD has apparently increased in proportion to the increasing incidence of obesity in both adults and children (Clark, 2006; Sathya et al., 2002).

Tetracycline is one of a group of drugs known to induce micro vesicular steatosis when triglyceride accumulation was concomitant with the inhibition of mitochondrial lipid metabolism (Amacher and Martin, 1997). Mechanisms by which tetracycline induces steatosis include the inhibition both of $\beta$ oxidation of free fatty acids and lipoprotein secretion from the liver (Letteron et al., 2003).

Researchers have examined the effects of plants used to support liver functions and treat diseases in the liver (Botha and Penrith, 2008; Maikai et al., 2010). However, herbs contain active substances that can trigger side effects and interact with other supplements or medications. For these reasons, herbs should be taken with care, under the supervision of practitioner knowledgeable in the field of botanical medicine. Recently researchers have examined the effects of plants used rationally by to support liver functioned and treat diseases of the liver (Varsha et al., 2011).

Ginger is a widely used spice and functional food. For centuries, ginger has been an important ingredient in herbal medicine. The medicinal properties attributed to ginger include anti-emetic (Tiran , 2012), cardiotonic, gastroprotective (Mustafa et al., 1994), anti-diabetic (Akhani et al. 2004), anti-arthritic (Bliddal et al., 2000), antimigraine (Cady et al ., 2005), anti-thrombotic (Thomson et al ., 2002), anti-fungal (Touba et al., 2012), anti-inflammatory (Thomson et al., 2002; Penna et al., 2003; Mahmoud et al., 2011), hypolipidaemic (Bhandari et al., 2005), hypocholesterolaemic (Furhman et al., 2000; Bhandari et al., 2005) and antioxidant activity(Oboh et al, 2012).

Since fatty liver causes were markedly increased in Egyptian people throughout last years, principal goal of the present study was to determine whether treatment with ginger could prevent factors induced fatty liver and to examine its effect on some vital organs as liver, kidney and heart.

\section{Material and Methods}

\section{Chemicals:}

- Oxytetracycline was obtained from El-Nile Pharmaceutical Company (Cairo, Egypt).

- Ginger was obtained in the form of powder and dissolved in distilled water $125 \mathrm{gm} /$ litter for 12 hours at room temperature then filtered (Kalantari and Rastmanesh, 2009).

\section{Experimental design:}

Thirty female albino rats of local strain weighting 150 - $200 \mathrm{gm}$. were obtained from ElNile Pharmaceutical Company (Cairo, Egypt). The animals were housed in metal cages (5 per cage), fed on balanced diet and water and maintained under prevailing atmospheric conditions with continuous cleaning and observation.

Rats were divided into two groups, the first group was to follow up the effect of the herb as a curative agent for fatty liver, while the second was to illustrate the effect of plant as a protective agent for fatty liver. Each group was divided into three subgroups, five rats for each.

\section{The first group was divided into:}

\section{1- Control:}

Rats were injected intraperitonealy with saline $(120 \mathrm{ml} / \mathrm{kg})$ for three consecutive days.

\section{2- Oxytetracycline:}

Rats were injected intraperitonealy with oxytetracycline $(120 \mathrm{mg} / \mathrm{kg})$ for three consecutive days for fatty liver induction (Nicola et al., 1996).

\section{3- Ginger curative:}

Rats were injected intraperitonealy with oxy tetracycline $(120 \mathrm{mg} / \mathrm{kg})$ for three consecutive days then orally administered ginger extract $(125 \mathrm{mg} / \mathrm{kg})$ daily by gastric tube for 30 days as a food supplement.

All animals were sacrificed after 33 days of the beginning of the experiment.

\section{The second group was divided into: 1- Control:}

Rats were injected intraperitonealy with saline $(120 \mathrm{ml} / \mathrm{kg})$ for three consecutive days then sacrificed. 


\section{Eman Helal .... et al}

\section{2- Fatty liver:}

Rats were injected intraperitonealy with oxytetracycline $(120 \mathrm{mg} / \mathrm{kg})$ for three consecutive days for fatty liver induction then sacrificed.

\section{3- Ginger recovery:}

Rats orally administered with ginger water extract (125mg/kg) daily by gastric tube for 15 days, then intraperitonealy injected with oxytetracycline $(120 \mathrm{mg} / \mathrm{kg})$ for three consecutive days then sacrificed.

\section{Blood sampling:}

The animals were anesthetized under light ether anaesthesia, blood samples were collected then the animals were sacrificed. Blood samples were kept for 30 minutes without disturbance then centrifuged for 15 - 20 minutes at $5000 \mathrm{rpm}$ to separate serum.

\section{Biochemical assays:}

Serum glucose was estimated according to enzymatic colorimetric method described by Tietz (1986). Alanine amino transferase (ALAT) and aspartate amino transferase (ASAT) were determined by the method of Breuer (1996). Serum $\gamma$-glutamyl transferase (GGT) was performed by kinetic method according to Persijn and Slik (1976). Serum total protein was estimated according to Doumas (1975). Serum albumin was determined according to the method of Dumas et al. (1997). The globulin value for each sample was obtained by substracting the albumin value from the corresponding total protein value. The $A / G$ ratio for each sample was obtained by dividing the albumin level to globulin level. Total lipids were assayed by the method of Kaplan (1984). Serum total cholesterol (T.C) was performed according to Henry et al. (1974). Serum triglycerides (T.G) were determined according to the method of Fossati and Prencie (1982). Serum high density lipoproteins cholesterol (HDL-cholesterol) was

assayed according to Burstein (1970). The concentration of low density lipoproteins cholesterol (LDL-cholesterol) in serum was estimated by the equation used by Friedewald $e t$ al. (1972) as follow:

$$
\begin{aligned}
& \text { LDL }- \text { cholestero l }(\mathrm{mg} / \mathrm{dl})= \\
& \text { Total cholestero l - HDL cholestero } 1-\left(\frac{\mathrm{T} . \mathrm{G}}{5}\right)
\end{aligned}
$$

Measurement of serum urea was done according to the method of Patton and Crouch (1977). Serum creatinine was evaluated according to the method of Jaffe (1986).

\section{Histological examination:}

For light microscopy, the liver was surgically removed from the rats at the end of each experimental period, fixed in $10 \%$ neutral buffered formalin, embedded in paraffin wax, sectioned at $5 \mu \mathrm{m}$ and stained with hematoxylin and eosin (Harris, 1900).

\section{Statistical Analysis:}

The results were expressed as mean \pm standard error (SE). The significance of differences between means was measured by student's t-test (Snedecor and Cochran, 1980). The $\mathrm{P}$ values below 0.05 were considered significant.

\section{Results}

\section{A- Biochemical results:}

The present data showed high significant increase $(\mathrm{P} \leq 0.01)$ in serum glucose level in fatty liver group when compared with control group (Table 1 ). Treatment of rats with ginger for 30 days after induction of

fatty liver with oxytetracycline caused significant increase $(\mathrm{P} \leq 0.05)$ in serum glucose level when compared with control group, while it showed high significant decrease $(\leq \mathrm{P} 0.01)$ when compared with fatty liver group.

On the other hand, giving ginger for 15 days as a protective agent before induction of fatty liver was recorded insignificant change in serum glucose level when compared with fatty liver group

(Table

1). 
Table (1): Effect of ginger on serum glucose level.

\begin{tabular}{|c|c|c|c|c|c|c|c|}
\hline & \multicolumn{3}{|c|}{ Treated group } & \multicolumn{3}{|c|}{ Protected group } \\
\hline & & Con & F.L & Gin & Con & F.L & Gin \\
\hline \multirow{4}{*}{$\begin{array}{c}\text { Serum } \\
\text { glucose } \\
\text { level } \\
\text { ( mg/dl ) }\end{array}$} & Mean & 74.1 & 95.0 & 79.8 & 74.9 & 96.1 & 94.7 \\
\hline & $\pm \mathrm{SE}$ & 1.48 & 1.22 & 1.3 & 1.4 & 1.3 & 1.1 \\
\hline & P1 & & $* *$ & $*$ & & $* *$ & $* *$ \\
\hline & $\mathbf{P} 2$ & & & $* *$ & & & N.S \\
\hline
\end{tabular}

Each value is the mean of 5 animals \pm SE.

N.S: non significant.

${ }^{*}$, **: is the significant difference when compared at $\mathrm{P} \leq 0.05$ and $\mathrm{P} \leq 0.01$ respectively.

P1: in comparison with control group.

P2: in comparison with fatty liver group.

Con: Control F.L: Fatty liver Gin: Ginger

A high significant increase $(\mathrm{P} \leq 0.01)$ in serum total lipids, triglycerides and LDL-cholesterol, while high significant decrease in HDL-cholesterol were recorded in fatty liver group when compared with control group (Table 2).

After induction of fatty liver followed by treatment with ginger for 30 days it was found insignificant change in serum cholesterol, triglycerides and LDL-cholesterol, while total lipids showed high significant increase $(\mathrm{P} \leq 0.01)$ when compared with control group and highly significant decreased when compared with fatty liver group. Serum HDL-cholesterol was significantly decreased when compared with control group and significantly increased when compared with fatty liver group.

On the other hand, ginger protective group recorded high significant increase $₫ \mathrm{P0.01)}$ in serum total lipids when compared with control group but remained less than fatty liver group.

Ginger protective group didn't affect triglycerides, cholesterol, LDL-cholesterol increase and HDLcholesterol reduction which caused by oxytetracycline in comparison with control and fatty liver rats. 
Table (2): Effect of ginger on lipid profile.

\begin{tabular}{|c|c|c|c|c|c|c|c|}
\hline & \multicolumn{3}{|c|}{ Treated group } & \multicolumn{3}{|c|}{ Protected group } \\
\hline & & Con & $\overline{\text { F.L }}$ & Gin & Con & $\overline{\text { F.L }}$ & Gin \\
\hline \multirow{4}{*}{$\begin{array}{c}\text { Total } \\
\text { Lipids } \\
\text { (mg/dL) }\end{array}$} & Mean & 309 & 411.4 & 322.8 & 306.2 & 408.8 & 403.4 \\
\hline & $\pm \mathrm{SE}$ & 2.7 & 2.1 & 1.6 & 2.1 & 1.6 & 1.6 \\
\hline & P1 & & $* *$ & $* *$ & & $* *$ & $* *$ \\
\hline & $\mathbf{P 2}$ & & & $* *$ & & & $*$ \\
\hline \multirow{4}{*}{\begin{tabular}{|} 
Triglycerid \\
es \\
(mg/dl)
\end{tabular}} & Mean & 42.4 & 90.4 & 56.9 & 41.3 & 89.5 & 85.2 \\
\hline & $\pm \mathrm{SE}$ & 1.9 & 1.4 & 1.3 & 1.1 & 1.3 & 1.4 \\
\hline & P1 & & $* *$ & N.S & & $* *$ & $* *$ \\
\hline & P2 & & & $*$ & & & N.S \\
\hline \multirow{4}{*}{\begin{tabular}{|c} 
Cholesterol \\
(mg/dl)
\end{tabular}} & Mean & 95.8 & 104.5 & 98.1 & 94.6 & 106.1 & 102.3 \\
\hline & $\pm \mathrm{SE}$ & 1.5 & 1.5 & 1.6 & 1.4 & 1.8 & 1.9 \\
\hline & P1 & & $* *$ & N.S & & $* *$ & N.S \\
\hline & P2 & & & * & & & N.S \\
\hline \multirow{4}{*}{$\begin{array}{c}\text { LDL } \\
\text { (mg/dl) }\end{array}$} & Mean & 40.6 & 48.02 & 44.0 & 38.5 & 48.1 & 46.3 \\
\hline & $\pm \mathrm{SE}$ & 2.88 & 1.4 & 0.92 & 1.3 & 1.4 & 1.8 \\
\hline & P1 & & * & N.S & & $* *$ & * \\
\hline & $\mathbf{P 2}$ & & & $*$ & & & N.S \\
\hline \multirow{4}{*}{$\begin{array}{l}\text { HDL } \\
\text { (mg/dl) }\end{array}$} & Mean & 46.7 & 38.4 & 42.7 & 47.8 & 39.9 & 39.0 \\
\hline & $\pm \mathrm{SE}$ & 1.6 & 1.2 & 1.2 & 1.3 & 1.4 & 1.4 \\
\hline & P1 & & $* *$ & $*$ & & $* *$ & $* *$ \\
\hline & P2 & & & * & & & N.S \\
\hline
\end{tabular}

Each value is the mean of 5 animals \pm SE .

N.S: non significant.

*,**: is the significant difference when compared at $\mathrm{P} \leq 0.05$ and $\mathrm{P} \leq 0.01$ respectively

P1: in comparison with control group.

P2: in comparison with fatty liver group.

Con: Control F.L: Fatty liver Gin: Ginger.

The present study showed that fatty liver group recorded high significant decrease $(P \leq 0.01)$ in serum total protein, albumin and globulin while A/G ratio was high significantly increased $\leqslant(\mathbf{B} .01)$ when compared with control group (Table 3).

Treating rats with ginger for 30 days after induction of fatty liver showed insignificant change on albumin, while total protein, globulin and A/G ratio showed high significant increase in comparison with control. In comparison with fatty liver group, ginger showed high significant increase $(\mathrm{P} \leq 0.01)$ in serum total protein, albumin and globulin while $A / G$ ratio showed insignificant change. On the other hand, giving ginger to rats for 15 days as a protective agent before induction of fatty liver was ameliorated the effect of oxytetracycline on serum total lipids, globulin and $A / G$ ratio. 
Table (3): Effect of ginger on serum protein profile (total proteins, albumin, globulin and A/G ratio) in treated and protected groups:

\begin{tabular}{|c|c|c|c|c|c|c|c|}
\hline & \multicolumn{3}{|c|}{ Treated group } & \multicolumn{3}{|c|}{ Protected group } \\
\hline & & Con & F.L & Gin & Con & F.L & Gin \\
\hline \multirow{4}{*}{$\begin{array}{c}\text { Total } \\
\text { Protein } \\
\text { ( g/dl ) }\end{array}$} & Mean & 7.5 & 5.7 & 7.0 & 7.6 & 5.3 & 5.8 \\
\hline & $\pm \mathrm{SE}$ & 0.08 & 0.09 & 0.1 & 0.1 & 0.08 & 0.1 \\
\hline & P1 & & $* *$ & $* *$ & & $* *$ & $* *$ \\
\hline & $\mathbf{P 2}$ & & & $* *$ & & & $* *$ \\
\hline \multirow{4}{*}{$\begin{array}{l}\text { Albumin } \\
\text { ( g/dl ) }\end{array}$} & Mean & 4.4 & 3.8 & 4.6 & 4.5 & 3.6 & 3.6 \\
\hline & $\pm \mathrm{SE}$ & 0.1 & 0.08 & 0.09 & 0.1 & 0.08 & 0.08 \\
\hline & P1 & & $* *$ & N.S & & $* *$ & $* *$ \\
\hline & $\mathbf{P 2}$ & & & $* *$ & & & N.S \\
\hline \multirow{4}{*}{$\begin{array}{l}\text { Globulin } \\
\text { ( g/dl ) }\end{array}$} & Mean & 3.1 & 1.9 & 2.4 & 3.1 & 1.7 & 2.1 \\
\hline & $\pm \mathrm{SE}$ & 0.08 & 0.08 & 0.05 & 0.06 & 0.08 & 0.08 \\
\hline & P1 & & $* *$ & $* *$ & & $* *$ & $* *$ \\
\hline & $\mathbf{P 2}$ & & & $* *$ & & & $* *$ \\
\hline \multirow{4}{*}{ A/G ratio } & Mean & 1.4 & 2.1 & 1.9 & 1.5 & 2.1 & 1.7 \\
\hline & $\pm \mathrm{SE}$ & $\mathbf{0 . 0 7}$ & 0.1 & 0.05 & 0.05 & 0.14 & 0.08 \\
\hline & P1 & & $* *$ & $* *$ & & $* *$ & $*$ \\
\hline & P2 & & & N.S & & & * \\
\hline
\end{tabular}

Each value is the mean of 5 animals \pm SE.

N.S: non significant.

*, **: is the significant difference when compared at $P \leq 0.05$ and $P \leq 0.01$ respectively.

P1: in comparison with control group.

P2: in comparison with fatty liver group.

The present results showed high significant increase (B 0.01) in activities of serum enzymes (ALAT, ASAT, GGT and LDH) in fatty liver group when compared with control group (Table 4).

Treating rats with ginger for 30 days after induction of fatty liver showed significant increase $(\mathrm{P} \leq 0.05)$ in serum ASAT and high significant increase $(\mathrm{P} \leq 0.01)$ in serum ALAT, GGT and LDH activities when compared with control group.

On the other hand, giving ginger for 15 days as a protective agent before induction of fatty liver was reduced the effect of oxytetracycline on GGT and LDH when compared with fatty liver group but still recorded high significant increase $(\mathrm{P} \leq 0.01)$ in these activities when compared with control group.

Ginger protective groups showed high significant $(\mathrm{P} \leq 0.01)$ increase in serum ASAT and ALAT activities when compared with control group and insignificant change when compared with fatty

liver group. 
Table (4): Effect of ginger on serum enzyme activities (ASAT, ALAT, GGT, LDH) in treated and protected groups:

\begin{tabular}{|c|c|c|c|c|c|c|c|}
\hline & \multicolumn{3}{|c|}{$\overline{\text { Treated group }}$} & \multicolumn{3}{|c|}{ Protected group } \\
\hline & & Con & $\overline{F . L}$ & Gin & Con & F.L & Gin \\
\hline \multirow{4}{*}{$\begin{array}{l}\text { ASAT } \\
\text { (U/ml) }\end{array}$} & Mean & 94.7 & 124.7 & $\begin{array}{l}99.3 \\
\end{array}$ & 95.1 & 126.1 & 124.6 \\
\hline & $\pm \mathrm{SE}$ & 1.1 & 1.38 & 1.43 & 1.02 & 1.64 & 1.23 \\
\hline & P1 & & $* *$ & $*$ & & $* *$ & $* *$ \\
\hline & $\mathbf{P 2}$ & & & $* *$ & & & N.S \\
\hline \multirow{4}{*}{$\begin{array}{l}\text { ALAT } \\
(\mathrm{U} / \mathrm{ml})\end{array}$} & Mean & 499.3 & 94.7 & 61.0 & 499.6 & 96.5 & 97.0 \\
\hline & $\pm \mathrm{SE}$ & 1.71 & 1.55 & 1.57 & 1.63 & 1.56 & 1.67 \\
\hline & P1 & & $* *$ & $* *$ & & $* *$ & $* *$ \\
\hline & $\mathbf{P 2}$ & & & $* *$ & & & N.S \\
\hline \multirow{4}{*}{$\begin{array}{c}\text { GGT } \\
(\mathbf{I u} / \mathbf{L})\end{array}$} & Mean & 10.04 & 21.34 & 10.98 & 10.7 & 21.1 & 17.3 \\
\hline & $\pm \mathrm{SE}$ & 0.33 & 0.73 & 0.19 & 0.26 & 0.69 & 0.19 \\
\hline & P1 & & ** & ** & & ** & $* *$ \\
\hline & $\mathbf{P 2}$ & & & $* *$ & & & $* *$ \\
\hline \multirow{4}{*}{$\begin{array}{c}\text { LDH } \\
\text { ( U/L ) }\end{array}$} & Mean & 179 & $\overline{523}$ & 247 & 185 & 2505 & 299 \\
\hline & $\pm \mathrm{SE}$ & 2.75 & 3.48 & 3.53 & 2.15 & 4.18 & 2.06 \\
\hline & P1 & & $* *$ & $* *$ & & $* *$ & $* *$ \\
\hline & $\mathbf{P} 2$ & & & $* *$ & & & $* *$ \\
\hline
\end{tabular}

Each value is the mean of 5 animals \pm SE.

N.S: non significant.

*, **: is the significant difference when compared at $\mathrm{P} \leq 0.05$ and $\mathrm{P} \leq 0.01$ respectively.

P1: in comparison with control group.

P2: in comparison with fatty liver group.

In the current data, fatty liver group recorded high significant increase $\leq(\mathrm{B} .01)$ in serum urea and creatinine when compared with control group (Table 5).

It was found that rats which treated with ginger for 30 days after or 15 days before induction of fatty liver showed amelioration on the effect of oxytetracycline on serum urea and creatinine levels but didn't return back to normal values.

Table (5): Effect of ginger on serum urea and creatinine in treated and protected groups.

\begin{tabular}{|c|c|c|c|c|c|c|c|}
\hline & \multicolumn{3}{|c|}{ Treated group } & \multicolumn{3}{|c|}{ Protected group } \\
\hline & & Con & F.L & Gin & Con & F.L & Gin \\
\hline \multirow{4}{*}{$\begin{array}{l}\text { Serum Urea } \\
\text { (mg/dl) }\end{array}$} & Mean & 37 & 203 & 53 & 28 & 204 & 67 \\
\hline & $\pm \mathrm{SE}$ & 2.6 & 8.6 & 3.6 & 1.2 & 6.3 & 1.9 \\
\hline & P1 & & $* *$ & $* *$ & & $* *$ & ** \\
\hline & P2 & & & $* *$ & & & $* *$ \\
\hline \multirow{4}{*}{$\begin{array}{l}\text { Serum } \\
\text { Creatinine } \\
\text { (mg/dl) }\end{array}$} & Mean & 0.71 & 2.1 & 0.95 & 0.63 & 1.7 & 1.0 \\
\hline & $\pm \mathrm{SE}$ & 0.02 & 0.1 & 0.04 & 0.02 & 0.1 & 0.04 \\
\hline & P1 & & $* *$ & ** & & $* *$ & $* *$ \\
\hline & P2 & & & $* *$ & & & $* *$ \\
\hline
\end{tabular}

Each value is the mean of 5 animals \pm SE.

N.S: non significant.

*, **: is the significant difference when compared at $\mathrm{P} \leq 0.05$ and $\mathrm{P} \leq 0.01$ respectively.

P1: in comparison with control group.

P2: in comparison with fatty liver group. 


\section{B- Histopathological results:}

The liver of control rat is formed of the classic hepatic lobules. Each lobule showed radially arranged hepatocytes forming cords around the central vein. Hepatocytes appeared polygonal in shape with rounded vesicular nuclei. Blood sinusoids were seen separating the cords of the liver cells and lined by flattened endothelial cells and von Kupffer cells (Plate 1, A).

Examination of liver sections of rats injected with oxytetracycline for three consecutive days showed apparent enlargement of hepatocytes reaching to ballooning. Cells all over the hepatic lobule were seen to contain mainly macro vacuoles dispersed throughout the cytoplasm (Plate 1, B). Some cells were seen having one large vacuole filling the whole cell with thin rim of cytoplasm around and pushing the nucleus to one side. Other cells were having smaller vacuoles with either central or eccentric nuclei (Plate 1, B).

After one month recovery period from oxytetracycline injection, many fat vacuoles, ballooned hepatocytes and apoptosis were abundant (Plate 1, C).

Section from rat treated with ginger for one month after induction of fatty liver by oxytetracycline demonstrated small fat droplets
(Plate 1, D) but less than those appeared in fatty liver group (Plate 1, B).

Sections from rats treated with ginger for 15 days before fatty liver induction demonstrated many small fat vacuoles and congested hepatic sinusoids (Plate 1, E) when compared to fatty liver group (Plate $1, \mathrm{~B}$ ).

Examination of the liver sections from normal rats showed normal parenchymal architecture and portal triad (Plate 2, A).

After treatment with oxytetracycline for three consecutive days, fatty liver indicated by many fat vacuoles. Wide portal area with dilated congested thickened portal vein and dilated bile duct were also seen (Plate 2, B).

In rats treated with oxytetracycline alone for three consecutive days and then recovery after one month, sections showed dilated congested portal vein, thickening of arteriole (Plate 2, C) and microvesicular fatty changes around the portal triad (Plate 2, B).

In ginger-treated group for one month after fatty liver induction, moderate to mild degenerated changes in hepatocytes and mild portal inflammation were observed (Plate 2, D). However, after treatment with ginger for 15 days then oxytetracycline for three consecutive days, many fat vacuoles (arrows) and congested portal vein were observed (Plate 2, E). No histopathological amelioration was observed. 

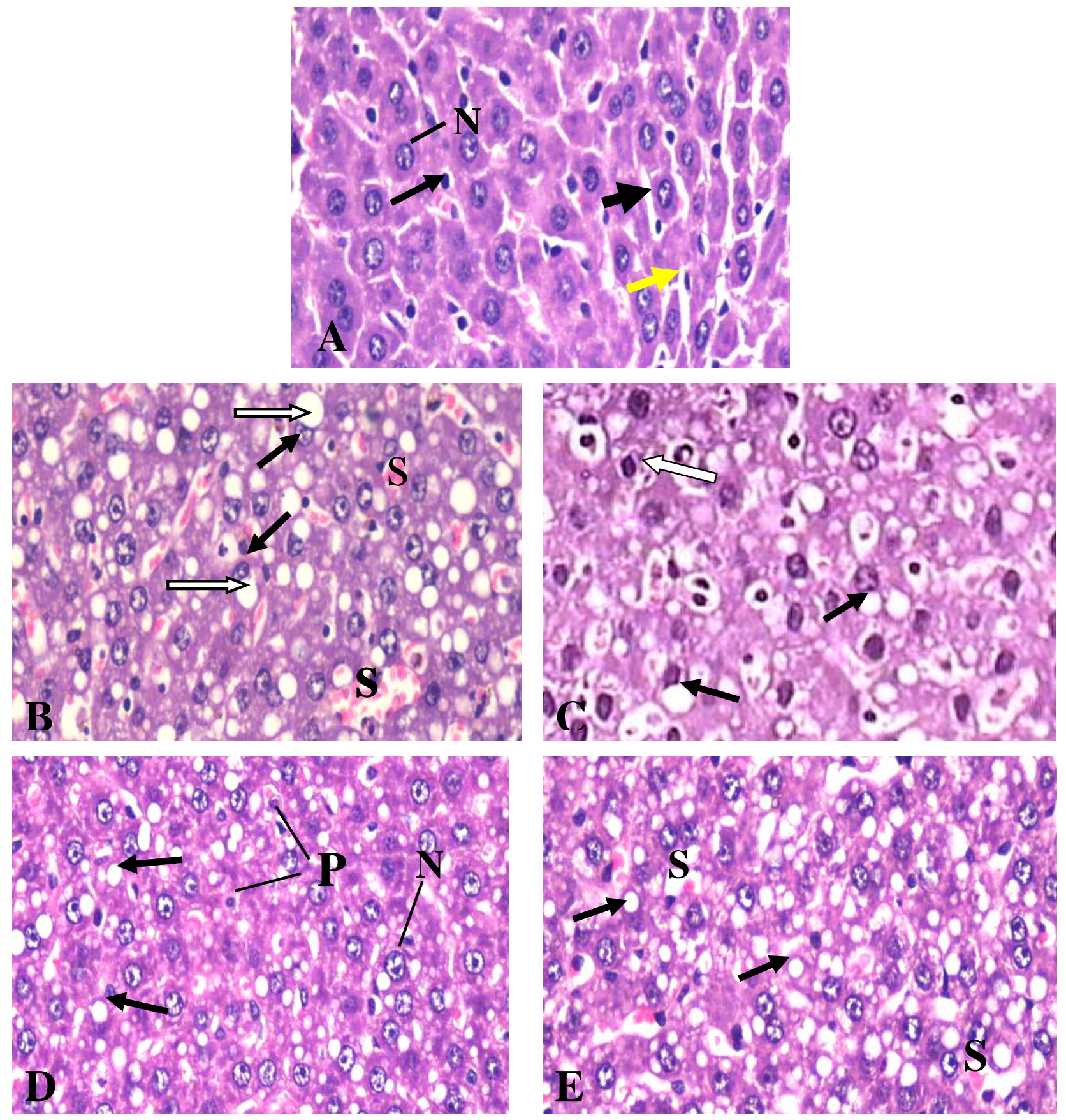

Plate 1: Photomicrograph of sections in livers of the examined rats (H \& E, X 400). A: Control, showing cords of hepatocytes separated by blood sinusoids (black arrow head) lined by flat endothelial (yellow arrow) and von Kupffer (black arrow) cells. The hepatocytes show vesicular nuclei $(\mathrm{N})$ and granular cytoplasm. B: After treatment with oxytetracycline for three consecutive days, fatty liver indicated by many fat vacuoles (white arrows), which occupy almost all the cytoplasm of hepatocytes, displacing nucleus (black arrows) to periphery. Dilated congested blood sinusoids (S) are also seen C: After treatment with oxytetracycline for three consecutive days and then recovery after one month, showing enlarged, ballooned hepatocytes with in-apparent sinusoids. Cells all over the hepatic lobule are having mainly macro vacuoles (black arrows) filling the cytoplasm. Notice that most of the cells have apoptosis (white arrow). D: After treatment with oxytetracycline for three consecutive days and ginger for one month, demonstrating many small fatty vacuoles (arrows). Notice that most of the cells have vesicular nuclei (N) and few have pyknotic nuclei (P) E: After treatment with ginger for 15 days and then injection with oxytetracycline for three consecutive days, demonstrating many fat vacuoles (arrows) and congested blood sinusoids (S). 

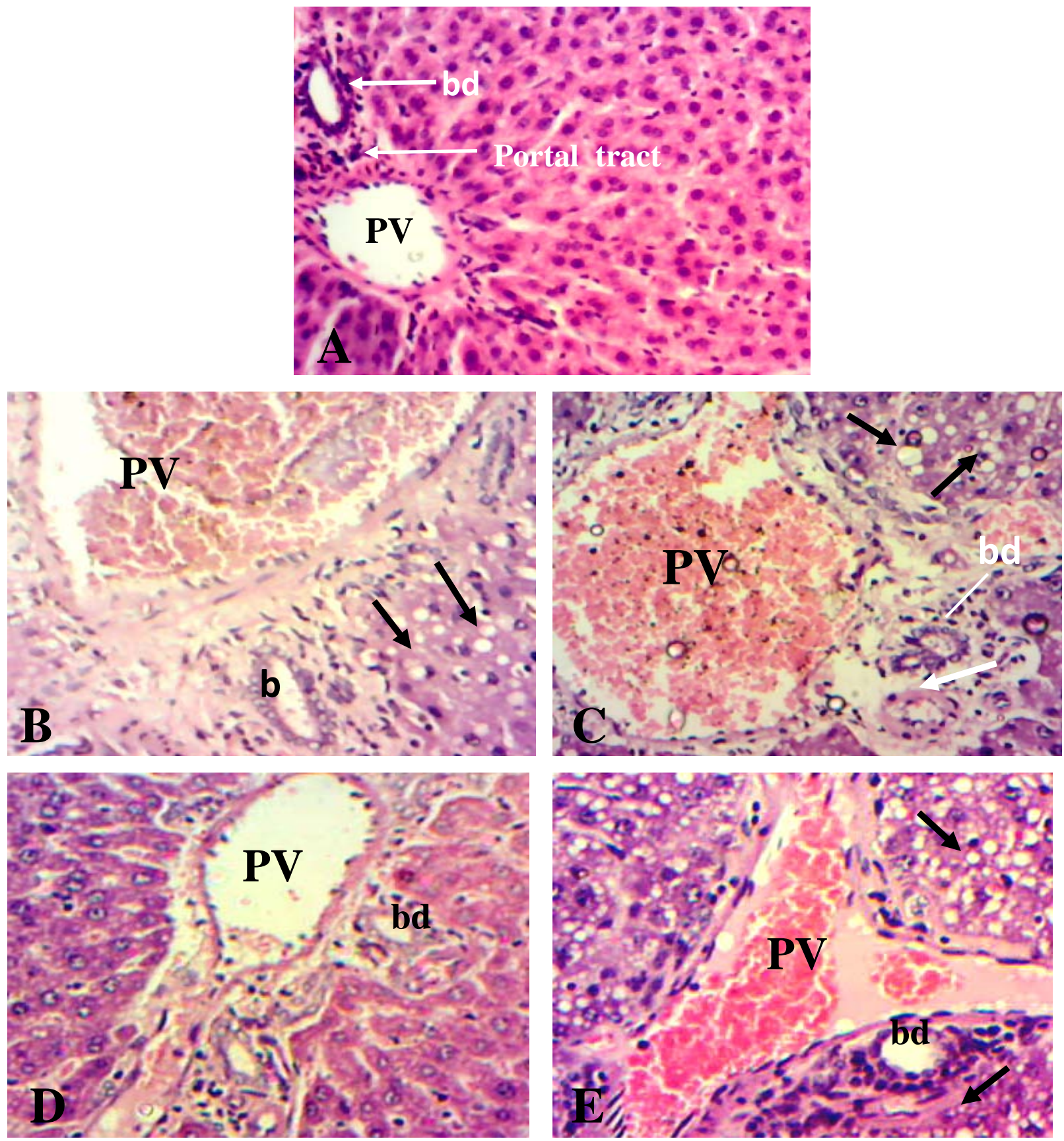

Plate 2: Photomicrograph of sections in livers of the examined rats (H \& E, X 400). A: Control, showing a portal vein (PV) and bile duct (bd). The hepatocytes show vesicular nuclei and granular cytoplasm. B: After treatment with oxytetracycline for three consecutive days, fatty liver indicated by many vacuoles (arrows). Wide portal area with dilated congested thickened portal vein (PV) and dilated bile duct (bd) are also seen. C: After treatment with oxytetracycline for three consecutive days and then recovery after one month, showing microvesicular fatty vacuoles (black arrows) around portal triad. Notice the dilated congested portal vein (PV) and thickened wall arteriole (white arrow). D: After treatment with oxytetracycline for three consecutive days and ginger for one month, demonstrating mild portal inflammation. E: After treatment with ginger for 15 days and then injection with oxytetracycline for three consecutive days, demonstrating many fat vacuoles (arrows) and congested portal vein (PV). 


\section{Eman Helal .... et al}

\section{Discussion}

NAFLD is a major health problem and evolving as the most common liver disease worldwide (Targher et al., 2010). Fatty liver causes were markedly increased in Egyptian people throughout last years. This high prevalence of NAFLD is probably problematic because patients with NAFLD show higher all-cause mortality and increased risks for liver-related death and cardiovascular disease (Adams et al., 2005; Arslan et al., 2007).The earliest stage of NAFLD is fatty liver that is defined as the presence of cytoplasmic triglyceride droplets in more than $5 \%$ of hepatocytes (Szczepaniak et al., 2005). Non-alcoholic steatohepatitis (NASH) is distinguished from simple fatty liver by the presence of hepatocyte injury such as hepatocyte ballooning and apoptosis, an inflammatory infiltrate, and/or collagen deposition. Over a time period of 10-15 years, $15 \%$ of patients with NASH will progress to liver cirrhosis (Targher and Arcaro, 2007). Once cirrhosis has developed, hepatic decompensation occurs at a rate of $4 \%$ annually while the ten-year risk of developing liver cancer is 10\% (Targher and Arcaro, 2007; Ekstedt et al., 2006).

The present study was conducted to evaluate the beneficial effect of ginger on fatty liver status induced by oxytetracycline in albino rats.

In this study, oxytetracycline injection to rats resulted in high significant increase in serum glucose level when compared with the control group. Changes in the serum glucose concentration under the effect of oxytetracycline were associated both with its inhibitory action on the absorbing function of the intestine and with the retarded glucose utilization in the tissues (Storozhuk and Shamsutdinova, 1981).

The present results showed hypoglycemic effect when fatty liver rats treated with ginger. The hypoglycemic effect of ginger extract is in agreement with Kar et al. (1999) who reported that, the inorganic part of ginger plant contains mainly mineral elements, which are responsible for the hypoglycemic activity. In support of this view, a number of essential minerals (Ca, Zn, K, $\mathrm{Mn}$ and $\mathrm{Cr}$ ), are known to be associated with the mechanisms of insulin release and its activity in different animals and in human beings (Castro,
1998). The blood glucose lowering effect of ginger may be due to the presence of inulin and oligofructose (Kaur and Gupta, 2002; Islam and Choi, 2008).

In addition, Akhani et al. (2004) reported that, ginger juice partially alleviated the hypoinsulinaemia observed in streptozotocin induced diabetic rats. This hypoglycaemic action of ginger may be due to its effects involving serotonin receptors, an increase in pancreatic secretion of insulin from $\beta$ cells or release of bound insulin.

Oral administration of ginger improved the degenerative of histopathological changes induced by fatty liver intoxication in liver. In this concern, it is reported that, the antihepatotoxic activity of ginger extract may be due to its direct radical scavenging activity (Ajith et al., 2007a).

In this study, oxytetracycline injection to rats resulted in high significant increase in serum cholesterol, triglycerides, LDL-cholesterol, while HDL-cholesterol was high significantly decreased. It was also induced acute pathological changes in the liver included narrowed blood sinusoidal lumina due to the enlarged, fat-laden hepatocytes together with necrosis. This finding correlates with the marked increase in serum cholesterol, triglycerides and LDL-cholesterol. The increased of these parameters in the blood is in correlation with the fatty degeneration of the liver (Gergely et al., 1995; Amacher and Martin, 1997). Biochemical mechanism for oxytetracycline toxicity based on mitochondrial damage as described by Asha et al. (2007).

The ameliorative effects of ginger on lipid profile in the present data are in agreement with Bhandari et al. (2005) who revealed that, ethanolic extract of ginger produced significant decrease in serum total cholesterol and triglycerides levels and increased HDLcholesterol level as compared to diabetic rats, and the extract exhibit a significant lipid lowering activity and protect the tissues from lipid peroxidation. Furthermore, Furhman et al. (2000) found that, ethanolic extract of ginger reduced plasma cholesterol and inhibited LDL oxidation in atherosclerotic, apolipoprotein Edeficient mice. It was concluded that (E)-8 beta, 17-epoxyllabed-12-ene-15, 16-dial, a compound 
isolated from ginger, interfered with cholesterol biosynthesis in liver homogenates of hypercholesterolaemic mice causing its reduction (Tanabe et al., 1993). In addition, Okamoto et al. (2011) reported that supplementation with [6]-gingerol analogue, a major chemical component of the ginger rhizome to mice fed a high-fat diet significantly reduced fat accumulation. Moreover, ginger may improve lipid metabolism in hyperlipidemic cholesterol enriched-diet rats (Matsuda et al., 2009).

Srinivasan and Sambaiah (1991) suggested that, feeding rats with ginger significantly elevated the activity of hepatic cholesterol 7-alphahydroxylase which is a rate-limiting enzyme in the biosynthesis of the bile acids and stimulates the conversion of cholesterol to bile acids leading to the excretion of cholesterol from the body. Moreover, the hypocholesterolaemic effect of ginger could have possibly resulted from the inhibition of cellular cholesterol biosynthesis after the consumption of the extract (Furhman et al., 2000). The reduction of cellular cholesterol biosynthesis is associated with increased activity of the LDL receptor, which in turn leads to enhanced removal of LDL from plasma, resulting in reduced plasma cholesterol concentration (Ness et al., 1996).

Furthermore, Lopes-Virella et al. (1983) reported that, the decreasing levels of plasma triglycerides following the treatment with ginger extract may be due to the stimulating effect of ginger extract on insulin. Insulin served to lower plasma triglycerides levels by returning lipoprotein lipase levels to normal. The triglyceride and cholesterol lowering effect could be related to the total lipid lowering effect by ginger (Bhandari et al., 2005; Nicoll and Henein, 2009). Saponins, flavonoids, and alkaloids have been previously reported in the crude extract of ginger (Ghayur and Gilani, 2005). The reduced lipid peroxidation in rat liver homogenates was reported to be due to total phenolics or flavonoids contents of some medicinal plants (Kery et al., 2001). Therefore the protective effect of plant extract against fatty liver may be attributed to the presence of triterpenoids and steroids. Phenolic compounds of ginger were also reported to exhibit strong antioxidant properties and cytoprotective actions in rats (Siddaraju and Dharmesh, 2007). Therefore it may be suggested that, the hepatoprotective effect of the tested plant is due at least partially to its content of flavonoids and or triterpenoids.

Estimation of the activity of ALAT, ASAT and GGT are good marker of assessment liver function. These enzymes are normally located in the cytosol of hepatocytes. When liver cells are damaged, these enzymes are released in the plasma and increased their activity in plasma is a useful marker of the extent and type hepatocellular damage (Atta et al., 2010) and subsequent altered plasma membrane permeability, causing their circulating levels to increase (Boyd, 1962).

Treated rats with oxytetracycline for three consecutive days caused fatty liver, necrosis and inflammation. These histological changes were associated with the high significant increase in activities of serum ALAT, ASAT, GGT and LDH. This is in agreement with Asha et al. (2007), who reported that, this significant increase may be due to rise in free radicals decrease in the antioxidant enzyme levels.

The significant decrease in serum transaminases ASAT, ALAT and GGT activities in ginger treated group elucidates the hepatoprotective effect of ginger (Yaccout et al., 2007).

The antioxidant, anti-inflammatory and free radical scavenging property of ginger was ameliorated the effect of oxytetracycline on serum LDH activity through scavenge the free radicals, minimize lipid peroxidation, thereby preventing membrane damage and leakage of enzymes (Suchalatha and Shyamala, 2004). It was suggested that, ginger may offer protection to the myocardium by preventing the lipid peroxidation of membrane bound polyunsaturated fatty acids, thus ensuring myocardial membrane function.

The present results clearly demonstrate the marked antihepatotoxic effects of ginger. This fact is based on the tendency of liver enzymes, glucose and triglycerides to return towards their respective levels in the normal control group. Previous studies have demonstrated that, ginger (Yemitan and Izegbu, 2006; Ajith et al., 2007a) exhibited hepatoprotective effect. The decreased liver enzymes in the present study below the oxytetracycline-treated or normal rats are 


\section{Eman Helal .... et al}

probably due to a membrane stabilizing effect of ginger.

In the present work, serum total protein, albumin and globulin were decreased in fatty liver induced group while $A / G$ was increased. This decrease could be related to hepatic dysfunction and decreased protein synthesis. Also it may be due to either damage of vital biological processes or to changes in permeability of liver, kidney and other tissue cells leading to leakage of protein via the kidney (Roushdy et al., 1989).

Administration of ginger after fatty liver induction was tolerated the hypoproteinemic effect of oxytetracycline due to its beneficial effects on liver and kidney functions.

In this study, oxytetracycline injection to rats resulted in high significant increase in serum urea and creatinine when compared with control group.

The mechanism of renal damage includes inhibiting protein synthesis and provoking a catabolic effect. Since the early 1950s, investigators have reported the propensity for renal side effects (Craig et al., 2009). In addition, an increase in kidney functions may occur due to the drug's anti-anabolic effect which, significantly impaired renal function, can lead to azotemia, hyperphosphatemia, and acidosis.

The present study revealed that, postadministration of ginger to fatty liver rats reduced and normalized the levels of plasma creatinine and urea. On the other hand, the pre-treatment with this plant before the induction of fatty liver inhibited the higher increase of plasma creatinine and urea but they did not normalized them.

Moreover, the study of Ajith et al. (2007b) demonstrated that, ethanol extract of ginger rendered significant protection against induced nephrotoxicity, which was evident from the lowered serum urea and creatinine levels in the mice that pre-treated with ginger extract. The presence of polyphenols and flavonoids in ginger extract might be responsible for the antioxidant nephroprotective activities and the reduction of serum urea and creatinine levels. Furthermore, the treatment of ginger extract could significantly prevent the depletion of antioxidant concentration and antioxidant enzymes activities in the kidneys. On the other hand, Mahmoud et al. (2012) reported that, ginger acts a renoprotective effect in renal failure. This protective effect may be attributed to its anti-inflammatory property as evident by attenuating serum C-reactive protein levels and antioxidant effects as evident by attenuating lipid peroxidation marker, malondialdehyde levels, and increasing renal superoxide dismutase activity.

\section{References}

Adams LA, Lymp JF, St Sauver J, Sanderson SO, Lindor KD, Feldstein A and Angulo P (2005): The natural history of nonalcoholic fatty liver disease: a population-based cohort study. Gastroenterology, 129 (1): 113-121.

Ajith T, Hema $U$ and Aswathy $M$ (2007a): Zingiber officinale Roscoe prevents acetaminopheninduced acute hepatotoxicity by enhancing hepatic antioxidant status. Food Chem. Toxicol., 45: 22672272.

Ajith T, Nivitha V and Usha S (2007b): Zingiber officinale Roscoe alone and in combination with alpha-tocopherol protect the kidney against cisplatininduced acute renal failure. Food Chem. Toxicol., 45: 921- 927.

Akhani S, Vishwakarma S and Goyal R (2004): Anti-diabetic activity of Zingiber officinale in streptozotocin-induced type I diabetic rats. J. Pharma. Pharmacol., 56: 101- 105.

Amacher D and Martin B (1997): Tetracyclineinduced steatosis in primary canine hepatocyte cultures. Fundam. Appl. Toxicol., 40: 256-263.

Arslan U, Turkoglu S, Balcioglu S, Tavil Y, Karakan $T$ and Cengel A (2007): Association between nonalcoholic fatty liver disease and coronary artery disease. Coron Artery Dis., 18 (6): 433-436.

Asha K, Snkar T and Viswanthan P (2007): Effect of tetracycline on pancreas and liver function of adult male albino rats. J.Pharma. Pharmacol., 59:12411248.

Atta A, Elkoly T, Mouneir S, Gehan K, Alwabe I and Shaimaa Z (2010): Hepatoprotective effect of methanol extract of Zingiber officinale and Cichorium intybus. Indian Journal of Pharmaceutical Sciences, 72: 564-570.

Bhandari U, Kanojia R and Pillai K (2005): Effect of ethanolic extract of Zingiber officinale on dyslipidaemia in diabetic rats. J. Ethnopharmacol., 97: 227- 230.

Bliddal H, Rosetzsky A, Schlichting P, Weidner $M$, Andersen L, Ibfelt $\mathrm{H}$, Christensen $\mathrm{K}$, Jensen $O$ and Barslev J (2000): Arandomized, placebo-controlled, cross-over study of ginger 
extracts and ibuprofen in osteoarthritis. Osteoarthritis Cartilage, 8: 9- 12.

Botha $C$ and Penrith $M$ (2008): Poisonous plants of veterinary and human importance in southern Africa. Jornal of Ethnopharmacology, 119 (3): 549 - 558.

Boyd J (1962): The comparative activity of some enzymes in sheep, cattle and rats. Normal serum and tissue levels changes during experimental liver necrosis. Res. Vet. Sci., 3: 256- 268.

Breuer J (1996): Report on the symposium drug effects in clinical chemistry methods. Eur. J. Clin. Chem. Clin. Biochem., 34: 385-386.

Burstein M (1970): Rapid method for isolation of lipoproteins from human serum by precipitation with poly-anion. J. lipid Research, 11: 583-588.

Cady R, Schreiber C, Beach $M$ and Hart C (2005): Gelstat Migrainew (sublingually administered feverfew and ginger compound) for acute treatment of migraine when administered during the mild pain phase. Med. Sci. Monit., 11: 165-169.

Castro V (1998): Chromium in series of portuguese plants used in the herbal treatment of diabetes. Biological Trace Elements Research, 62 (1-2): 101106.

Clark JM (2006): The epidemiology of nonalcoholic fatty liver disease in adults. J. Clin. Gastroenterol., 40: 5-10.

Craig B, Qingqing W, Sung-Gyu C and Zheng D (2009): Regulation of mitochondrial dynamics in acute kidney injury in cell culture and rodent models. J. Clin. Invest., 119:1275-1285.

Doumas BT (1975): Standards for Total Serum Protein Assays- A Collaborative Study. Clin. Chem., 21(8): 1159-1166.

Dumas BT, Watson WA and Biggs HG (1997): Albumin standards and the measurement of serum albumin with bromcresol green. Clin. Chim. Acta, 258 (1): 21-30.

Ekstedt M, Franzén LE and Mathiesen UL (2006): "Long-term follow-up of patients with NAFLD and elevated liver enzymes," Hepatology, 44(4): 865-873.

Fossati P and Prencie L (1982): Serum triglycerides determined colorimeterically with an enzyme that produces hydrogen peroxide. Clin. Chem., 28: 20772080.

Friedewald T, Levy $R$ and Fredrichsor D (1972): Estimation of the concentration of low-density lipioprotein cholesterol in plasma without use of the preparative ultracentrifuge. Clin. Chem., 18: 499502.

Furhman B, Roseblate M, Hayek T, Coleman R and Aviram M (2000): Ginger extract consumption reduces plasma cholesterol, inhibits LDL oxidation and attenuates development of atherosclerosis in atherosclerotic, apolipoprotein E-deficient mice. J. Nutr., 130: 1124 - 1131.

Gergely J, Kulcsar A and Harsfalvi J (1995): Changes in fat metabolism in acute carbon tetrachloride intoxication of rats. Acta. Pharm. Hung. 65(1): 3-4.

Ghayur MN and Gilani AH (2005): Ginger lowers blood pressure through blockade of voltagedependent calcium channels. Dig. Dis. Sci., 50:18891897.

Harris H (1900): Histochemical technique by Methuan and Co. LTD. London. Pp: 205-209. After Bruse, Casselman. W. G. (1959):

Henry R, Cannon D and Winkelman J (1974): Clinical Chemistry Principles and Techniques, Harper and Row. New York, Pp: 1440-1452.

Islam MS and Choi H (2008): Comparative effects of dietary ginger (Zingiber officinale) and garlic (Allium sativum) investigated in a type 2 diabetes model of rats. J. Med. Food, 11: 152 - 159.

Jaffe M (1986): Quantitative colorimetric determination of creatinine in serum or urine. $\mathrm{Z}$. Physiol. Chem., 10: 391-400.

Kalantari $H$ and Rastmanesh $M$ (2009): Protective property of Cichorium intybus in $\mathrm{CCl}_{4}$ induced liver damage in mice. Arch. Iran Med., 3: 46- 47.

Kaplan A (1984): Quantitative determination of total lipids. Clin. Chem., 22: 919-932.

Kar A, Choudhary B and Bandyopadhyay $\mathbf{N}$ (1999): Preliminary studies on the inorganic constituents of some indigenous hypoglycaemic herbs on oral glucose tolerance test. J. Ethnopharmacol. 64 (2): 179 - 184.

Kaur N and Gupta AK (2002): Applications of inulin and oligofructose in health and nutrition. J. Biosci., 27: 703 - 714.

Kery A, Blazovics A, Fejes S, Nagy E, Lugasi A and Kursinszki L (2001): Antioxidant activity of medicinal plants used in phytotherapy. Int. J. Hortcultural. Sci., 7: 28 - 35.

Letteron P, Sutton A, Mansouri A, Fromenty B and Pessayre D (2003): Inhibition of microsomal triglyceride transfer protein: Another mechanism for drug-induced steatosis in mice. Hepatology, 38: 133140.

Lopes -Virella M, Whitmann H, Mayfield P, Loadhott $C$ and Colwell J (1983): Effect of metabolic control on lipid, lipoprotein and apolipoprotein levels in 55 insulin-dependent diabetic patients: a longitudinal study. Diabetes, 32: $20-25$.

Mahmoud MF, Diaai AA, Ahmed F and Ren F (2012): Evaluation of the efficacy of ginger, arabic gum, and boswellia in acute and chronic renal failure. 34(1):73-82. 


\section{Eman Helal .... et al}

Maikai V, Kobo $P$ and Maikai $B$ (2010): Antioxidant properties of Ximenia Americana. African Journal Biotechnology, 9 (45): 7744 - 7746.

Marchesini G, Brizi M, Blanchi G (2001): Nonalcoholic fatty liver disease: a feature of the metabolic syndrome. Diabetes, 50 (8):1844-1850.

Matsuda A, Wang Z, Takahashi S, Tokuda T, Miura $N$ and Hasegawa $J$ (2009): Upregulation of mRNA of retinoid binding protein and fatty acid binding protein by cholesterol enriched-diet and effect of ginger on lipid metabolism. Life Sci., 84 (25-26): 903-907.

Mustafa T, Srivastava $K$ and Jensen K (1994): Drug development report (9): Pharmacology of ginger, Zingiber officinale. J. Drug Dev., 6: 25 - 39.

Ness G, Zhao Z and Lopez D (1996): Inhibitor of cholesterol biosynthesis increase hepatic low density lipoprotein receptor protein degradation. Arch. Biochem. Biophys., 325: 242 - 248.

Nicola W, Ibrahim K, Mikkail T, Girgis R and Khadr M (1996): Role of hypoglycemic plant extract Cleom droserifolia in improving glucose and lipid metabolism and its relation to in insulin resistance in fatty liver. Bull. chem. farmacutica., 135 (9): 507-517.

Nicoll R and Henein MY (2009): Ginger (Zingiber officinale Roscoe): A hot remedy for cardiovascular

Oboh G, Akinyemi AJ and Ademiluyi AO (2012): Antioxidant and inhibitory effect of red ginger (Zingiber officinale var. Rubra) and white ginger (Zingiber officinale Roscoe) on Fe $(2+)$ induced lipid peroxidation in rat brain in vitro. Exp. Toxicol. Pathol., 64(1-2): 31-36.

Patton C and Crouch S (1977): A colorimetric method for the determination of blood urea concentration. J. Anal. Chem., 49: 464-469.

Penna S, Medeiros M, Aimbire F, Faria-Neto $H$, Sertie $J$ and Lopes $R$ (2003): Anti-inflammatory effect of the hydralcoholic extract of Zingiber officinale rhizomes on rat paw and skin edema. Phytomed., 10: 381- 385.

Persijn J, Slik W and Van D (1976): A new method for the determination of gamma glutamyltransferase in serum. Clin. Chem. Biochem., 14(9): 421 - 427.

Ratziu V, Bellentani S, Cortez-Pinto H, Day C and Marchesini $G$ (2010): A position statement on NAFLD/NASH based on the EASL 2009 special conference. Journal of Hepatology, 53(2): 372-384.

Roushdy H, El-Hussaini $M$ and Saleh F (1989): Effect of whole-body gamma-irradiation and/or dietary protein deficiency on levels of plasma nonprotein-nitrogen and amino acids in desert rodents and albino rats. Egypt. J. Rad. Sci. Applic., 1: 156166.
Sathya P, Martin S and Alvarez F (2002): Nonalcoholic fatty liver disease (NAFLD) in children. Curr Opin Pediatr., 14:593-600.

Shulman AI and Mangelsdorf DJ (2005): Retinoid $\mathrm{X}$ receptor heterodimers in the metabolic syndrome. The New England Journal of Medicine, 353(6): 604615.

Siddaraju MN and Dharmesh SM (2007): Inhibition of gastric $\mathrm{H}+, \mathrm{K}+$-ATPase and Helicobacter pylori growth by phenolic antioxidants of Zingiber officinale. Mol. Nutr. Food Res., 51: 324-432.

Snedecor G and Cochran W (1980): Statistical methods. Oxford and J. B. H. Publishing Co., $7^{\text {th }}$ ed.

Srinivasan K and Sambaiah K (1991): The effect of spices on cholesterol 7 alpha-hydroxylase activity and on serum and hepatic cholesterol levels in the rat. Int. J. Vitam. Nutr. Res., 61: 364 - 369.

Storozhuk $P$ and Shamsutdinova V (1981): Effect of certain antibiotics of tetracycline series on the level of blood sugar and the role of insulin in the mechanism of its regulation. Probl. Endokrinol., 22 (6): 106-110.

Suchalatha S and Shyamala C (2004): Effect of arogh -apolyherbal formulation on the marker enzymes in isoproterenol induced myocardial injury. Indian Journal Clinical Biochemistry, 19 (2): 184189

Szczepaniak LS, Nurenberg $\mathbf{P}$ and Leonard D (2005): Magnetic resonance spectroscopy to measure hepatic triglyceride content: prevalence of hepatic steatosis in the general population. American Journal of Physiology Endocrinology and Metabolism, 288 (2): 462-468.

Tanabe M, Chen Y, Saits K and Kano Y (1993): Cholesterol biosynthesis inhibitory component from Zingiber officinale Roscoe. Chem. Pharm. Bull., 41: $710-722$.

Targher G and Arcaro G (2007): "Non-alcoholic fatty liver disease and increased risk of cardiovascular disease”. Atherosclerosis, 191(2): 235-240.

Targher G, Day CP and Bonora E (2010): "Risk of cardiovascular disease in patients with nonalcoholic fatty liver disease," New England Journal of Medicine, 363 (14): 1341-1350.

Thomson M, Al-Qattan K, Al-Sawan S, Alnaqeeb A, Khan I and Ali M (2002): The use of ginger (Zingiber officinale Rosc.) as a potential antiinflammatory and anti-thrombotic agent. Prostagl. Leukotr. Essen. Fatty Acids, 67: 475 - 478.

Tietz P (1986): Textbook of clinical chemistry. W.B. Saunders Co., London, Pheladelphia, P. 796.

Tiran D (2012): Ginger to reduce nausea and vomiting during pregnancy: Evidence of effectiveness is not the same as proof of safety. Complement Ther. Clin. Pract., $\quad$ 18(1): 22-25. 
Touba EP, Zakaria M, Tahereh E (2012): Antifungal activity of cold and hot water extracts of spices against fungal pathogens of Roselle (Hibiscus sabdariffa) in vitro. Microb Pathog., 52(2):125-129.

Varsha K, Amit $k$ and Abhinav A (2011): Hepatoprotective prospective of herbal drugs and their vesicular carriers. International Journal Research Pharmaceutical Biomedical Sciences, 2 (2): 360 - 374.
Yaccout G, El-Guindy N and El-Azab E (2007):

Amelioretic effect of Zingiber officinale on experimentally induced liver fibrosis in rats. J. Med. Res. Instit., 28 (2): 154 - 159.

Yemitan OK and Izegbu MC (2006): Protective effects of Zingiber officinale (Zingiberaceae) against carbon tetrachloride and acetaminophen-induced hepatotoxicity in rats. Phytother. Res., 20: 997-1002. 


\section{تاثير الزنجبيل على الكبد الدهنى المستحدث بواسطة مركب الأوكسى تتراسيكلين فى الجرذان.}

*ايمان جمال الدين عزت هلال، *سامية محمد عبد الوهاب ، **عاطف محمد موسى شرف، *غادة عادل زيدان

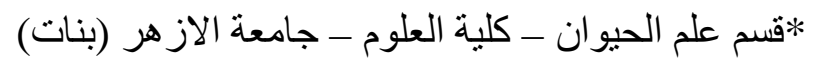

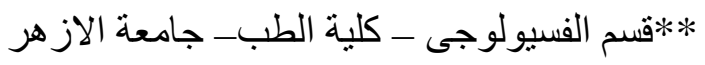

أسباب حدوث الكبد الدهنى قد تزيد زيادة ملحوظة في مصر خلال السنوات الأخيرة. ويفضل الناس إستخدام

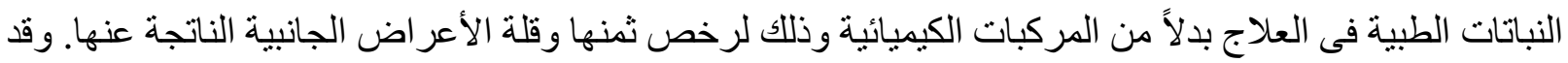

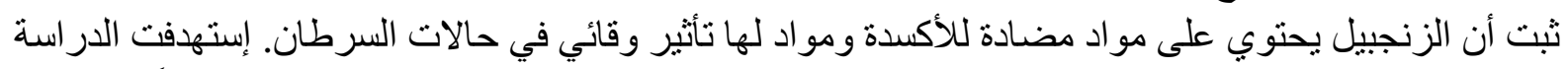

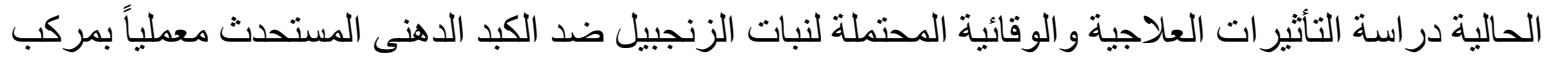
الأوكسى تتر اسيكلين وذللك لمحاولة فهم آلية عمل هذا النبات والتى قد تمهد الطريق لتطبيقات النيات علاجية ممكنة.

تم تقسيم الحيو انات إلى مجمو عتين رئيسيتين، كل مجمو عة تحتوى على 15 عينة: 1 - المجمو عة الأولى (لدر اسة التأثير العلاجى للزنجبيل) وقد قسمت إلى ثلاثة مجمو عات:

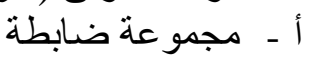
ب ـ ـ مجموعة إستثفائية: تم إصابتها بالكبد الدهنى عن طريق المعاملة بمركب الأوكسى تتر اسيكلين (120) ج - مجمو عة علاجية: تم معاملتها بمستخلص مائي للزنجبيل (70مجم/كجم) لمدة 30 يو بعد إصابتها بالكبد

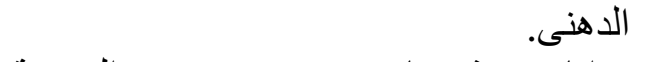
جميع الحيو انات تم ذبحها بعد 33 يوم من بدء التجربة. 2 - المجمو عة الثانية (لدر اسة التأثثر الوقائى للزنجبيل) وقد قسمت إلى ثلاثة مجمو عات:

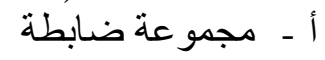

ب ـ ـمجموعة مصابة بالكبد الدهنى: عن طريق المعاملة بمركب الأوكسى تنر اسيكلين (120مجم/كجم ) لمدة 3 ايام متتالية ثم تم ذبحها.

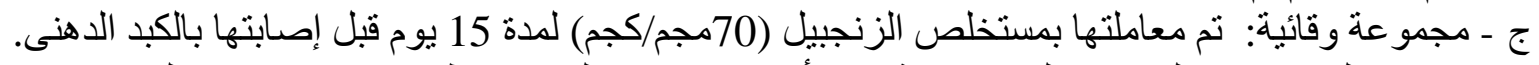

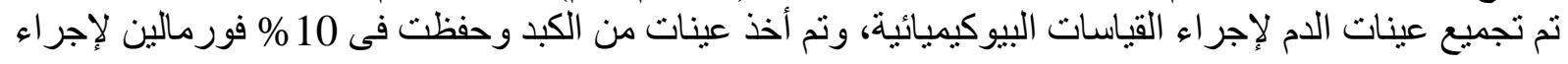

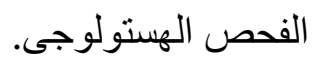

أظهرت المجمو عات المصابة بالكبد الدهنى زيادة ملحوظة فى مستوى الجلوكوز بالدم، الكوليستيرول، الدهون

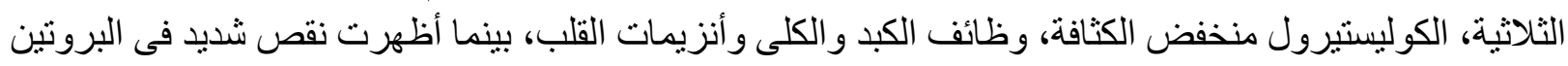

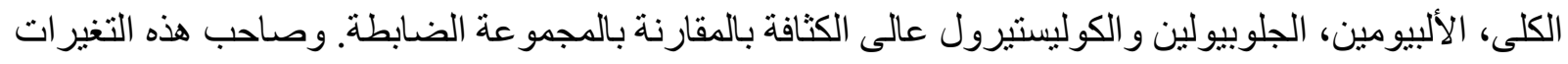

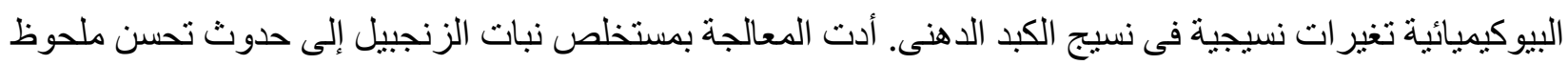

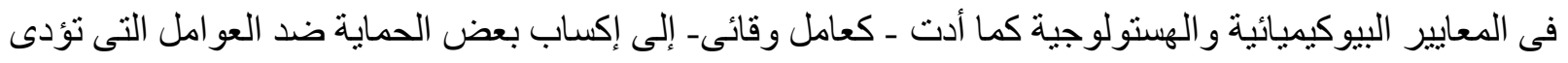

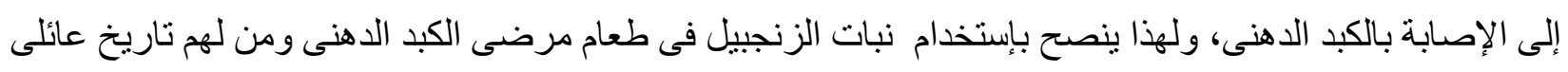

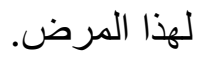

